\title{
Oregano essential oil (Origanum vulgare) to feed laying hens and its effects on animal health
}

\author{
MARCOS J. MIGLIORINI ${ }^{1}$, MARCEL M. BOIAGO ${ }^{2}$, LENILSON F. ROZA ${ }^{3}$, MAURICIO \\ BARRETA $^{2}$, ALESSANDRA ARNO ${ }^{8}$, WEBER S. ROBAZZA ${ }^{3}$, ALESSANDRO C. GALVÃO ${ }^{4}$, \\ GABRIELA M. GALLI ${ }^{2}$, GUSTAVO MACHADO ${ }^{5}$, MATHEUS D. BALDISSERA ${ }^{6}$, ROGER \\ WAGNER $^{7}$, LENITA C.M. STEFANI ${ }^{2}$ and ALEKSANDRO S. DA SILVA ${ }^{2}$ \\ ${ }^{1}$ Programa de Pós-Graduação em Ciência Animal, Universidade do Estado de Santa Catarina/ \\ UDESC, Av. Luiz de Camões, 2090, Conta Dinheiro, 88520-000 Lages, SC, Brazil \\ ${ }^{2}$ Departmento de Zootecnia, Universidade do Estado de Santa Catarina/UDESC, Rua Beloni \\ Trombeta Zanin, 608E, Santo Antônio, 89815-630 Chapecó, SC, Brazil \\ ${ }^{3}$ Programa de Pós-Graduação em Zootecnia, Universidade Estadual de Maringá/UEM, \\ Av. Colombo, 5790, Jd. Universitário, 87020-900 Maringá, PR, Brazil \\ ${ }^{4}$ Departamento de Engenharia de Alimentos e Engenharia Química, Universidade do Estado de Santa Catarina/ \\ UDESC, Rua Fernando de Noronha, Km 573, BR 282, 89870-000 Pinhalzinho, SC, Brazil \\ ${ }^{5}$ Laboratório de Epidemiologia Veterinária, Universidade Federal do Rio Grande do Sul/ \\ UFRGS, Av. Paulo Gama, 110, Farroupilha, 90040-060 Porto Alegre, RS, Brazil \\ ${ }^{6}$ Departmento de Parasitologia e Microbiologia, Universidade Federal de Santa Maria/ \\ UFSM, Av. Roraima, 1000, Camobi, 97105-900 Santa Maria, RS, Brazil \\ ${ }^{7}$ Departmento de Tecnologia de Alimentos, Universidade Federal de Santa Maria/ \\ UFSM, Av. Roraima, 1000, Camobi, 97105-900 Santa Maria, RS, Brazil \\ ${ }^{8}$ Programa de Pós-Graduação em Ciência Animal e Pastagens, Escola Superior de Agricultura "Luiz de Queiroz", \\ Universidade de São Paulo/USP, Av. Pádua Dias, 11, Piracicaba, 13418-900 São Paulo, SP, Brazil \\ Manuscript received on November 10, 2017; accepted for publication on May 24, 2018
}

\begin{abstract}
How to cite: MIGLIORINI MJ, BOIAGO MM, ROZA LF, BARRETA M, ARNO A, ROBAZZA WS, GALVÃO AC, GALLI GM, MACHADO G, BALDISSERA MD, WAGNER R, STEFANI LCM AND SILVA AS. 2019. Oregano essential oil (Origanum vulgare) to feed laying hens and its effects on animal health. An Acad Bras Cienc 91: e20170901. DOI 10.1590/0001-3765201920170901.

Abstract: This study evaluated the effect of oregano essential oil added to the feed of commercial laying hens. This research was focused on the analysis of biochemical changes linked to hepatic function, and protein and lipid metabolism. It was used 240 laying hens (59 weeks-old) distributed in a completely randomized design of six treatments (five repetitions with eight birds each). The experiments were constituted by a control treatment (CT) with the inclusion of zinc bacitracin and five treatments of oregano essential oil (OEO: 0, 50, 100, 150, and $200 \mathrm{mg} . \mathrm{kg}-1$ ), respectively. After 28 days of feeding, an increase on serum levels of total proteins and globulins was observed on groups T150 and T200, as well as an increase on albumin levels on group CT. After 84 days of feeding, a significant reduction on total proteins and albumin was observed on group T200, as well as an increase in serum triglycerides. OEO at 200 mg.kg-1 increased globulin levels on day 28 , which may be considered an effect in the inflammatory response, which increases serum immunoglobulins and proteins.
\end{abstract}

Key words: albumin, cholesterol, globulin, total proteins, triglycerides, health.

Correspondence to: Marcel M. Boiago

E-mail:mmboiago@gmail.com

ORCid: http://orcid.org/0000-0002-0950-4577 


\section{INTRODUCTION}

The search of new alternatives for feed supplementation in poultry production in order to improve animal health, and quantitative and qualitative productivity is considered one of the main priorities (Gerzilov et al. 2015). Essential oils are a mixture of several compounds of herbal origin, that can be used for animal feeding to improve its performance and health (Roofchaee et al. 2011). Oregano essential oil when used in the diet may exert antioxidant property since it has two important phenol compounds, corresponding to $78-85 \%$ of the oil composition, i.e., carvacrol (2-methyl5-isopropyiphenol) and thymol (2-isopropyl-5methylphenol) (Basmacioglu Malayoğlu et al. 2010). According to Botsoglou et al. (2002), these compounds enter the circulatory system, being distributed to muscles and other tissues. Moreover, this oil possesses antimicrobial activity, acting in the reduction of undesirable intestinal microflora, which favors the absorption of nutrients (Bampidis et al. 2005).

Essential oils can act as stimulant agents of the immune system during acute or chronic inflammatory processes that can be characterized by an increase on the levels of serum globulins (Rosa Neto and Carvalho 2009), which can express the metabolic and nutritional status of the animal (Zhu et al. 2014). Moreover, essential oils may improve nutrient digestion and absorption by enzymatic stimulation and they also may exert positive effects when used in laying hens. It is important to emphasize that the response of essential oils as supplements added in the feed depends on the level, composition, and the 44 combination of their compounds (Zhang et al. 2005).

It is known that the addition of thymol in the diet of chickens reduces the serum levels of cholesterol (Case et al. 1995), without any effect on laying hens (Abdel-Wareth 2016). The action of this compound on cholesterol synthesis is linked with the inhibition on the production of 3-hydroxy-3- methylglutaryl coenzyme A (HMG-CoA) reductase, a regulatory enzyme involved in the synthesis of cholesterol (Bampidis et al. 2005). The absence or presence of this effect depends on several factors, such as race, lineage, age and feed composition (Lee et al. 2003a). In addition, evidences suggest that thymol protects the intestinal microvilli responsible for the absorption of nutrients, influencing positively the secretion of endogenous digestible enzymes and influencing blood constituents (Hashemipour et al. 2013). A study revealed that carvacrol was more efficient to reduce plasmatic triglycerides compared to thymol (Lee et al. 2003b). Moreover, high supplementation of 56 oregano essential oil causes an increase on the serum levels of cholesterol in chickens (Basmacioglu Malayoğlu et al. 2010), suggesting that optimal concentrations of these lipids may have the same effect in laying hens, which is the main objective of this study. Based on these evidences, the aim of this study was to evaluate whether the addition of oregano essential oil in different concentrations in the feed of laying hens causes a positive effect on hepatic function, as well as on lipid and protein metabolism of commercial laying hens.

\section{MATERIALS AND METHODS}

All procedures were carried out according to the international practices for animal use and care, approved by the Committee of Ethics on Animal Experimentation, from the Santa Catarina State University, protocol no. 1.39.15.

\section{BIRD HUSBANDRY}

A total of 240 commercial Hy-Line Brown laying hens, 59 weeks-old with average body weight of $1890 \pm 5 \mathrm{~g}$ were used in this study. The birds were allocated in an experimental house type Californian equipped with galvanized wire cages $(100 \times 40 \times 45$ $\mathrm{cm})$. The birds received water ad libitum by nipple 
drinkers and $16 \mathrm{~h}$ of light. The experiment lasted 84 days, divided into three cycles of 28 days.

\section{EXPERIMENTAL DESIGN AND ANIMAL DIETS}

The hens were randomly assigned to six treatment groups with five replicates of eight hens. The basal diet (Table I) was formulated in accordance with Rostagno et al. (2011), with the inclusion $(2 \%)$ of a mineral and vitamin commercial blend. The control treatment (CT) consisted of a basal diet with a performance improver (30 $\mathrm{mg}$ of zinc bacitracin per $\mathrm{kg}$ of feed). Five treatment groups named (T0, T50, T100, T150 and T200) were used without bacitracin but supplemented with five concentrations of OEO $(0,50,100,150$ and 200 $\left.\mathrm{mg} . \mathrm{kg}^{-1}\right)$, respectively. The OEO was diluted in soy oil and subsequently the mixture was mixed with ground corn in a vertical mixer.

\section{OEO EXTRACTION AND CHARACTERIZATION}

The OEO was extracted from a dehydrated Origanum vulgare of Chilean origin by the steam distillation method. The herbal sample was placed in an extraction flask and the distillation was kept for 2 hours. The average of the extraction yield was $0.8 \%$. The OEO characterization was performed using a gas chromatographer Varian Star 3400CX (CA, EUA) equipped with a flame ionization detection (GC-FID). The qualitative analyses of oil compounds were performed using a gas chromatograph Shimadzu QP2010 Plus coupled to a mass spectrometer (GC/MS, Shimadzu 91 Corporation, Kyoto, Japan). The analyses revealed different compounds where five of them represented $54.56 \%$ (Figure 1).

\section{SAMPLING}

At the end of each cycle (days 28, 56 and 84 of the experiment) two hens per cage (10 hens/treatment) were randomly selected for blood sampling. Blood was collected from the branchial vein into non-
TABLE I

Percentual and calculated composition of experimental ration used to the treatment of laying hens.

\begin{tabular}{lc}
\hline Ingredients & Composition (\%) \\
\hline Maize & 65.95 \\
Soybean meal & 21.75 \\
Soy oil & 1.10 \\
Limestone & 9.20 \\
Vitamin and Mineral Core * & 2.00 \\
\hline Total & 100 \\
\hline Calculated composition & \\
\hline Crude protein (\%) & 15.60 \\
Metabolic energy(kcal/kg) & 2.850 \\
Available phosphorus (\%) & 0.275 \\
Calcium (\%) & 3.85 \\
Sodium (\%) & 0.211 \\
Digestible lysine (\%) & 0.684 \\
Digestible methionine + cysteine (\%) & 0.622 \\
Digestible methionine (\%) & 0.342 \\
Digestible threonine (\%) & 0.520 \\
\hline
\end{tabular}

* Product composition $(\mathrm{kg})$ : folic acid $54,00 \mathrm{mg}$, nicotinic acid $1.000,00 \mathrm{mg}$, pantothenic acid $680,00 \mathrm{mg}$, biotin 2,70 $\mathrm{mg}$, calcium $80,00 / 160,00 \mathrm{~g}$, cobalt $27,0 \mathrm{mg}$, cooper $6.000,00$ $\mathrm{mg}$, choline $10,00 \mathrm{~g}$, iron $5.000,00 \mathrm{mg}$, phytase $20,00 \mathrm{ftu}$, fluorine $650,00 \mathrm{mg}$, phosphorus $42,00 \mathrm{~g}$, iodine $40,00 \mathrm{mg}$, manganese $2.500,00 \mathrm{mg}$, mineral matter $900,00 \mathrm{~g}$, methionine $38,00 \mathrm{~g}$, selenium $10,00 \mathrm{mg}$, sodium $95,00 \mathrm{~g}$, humidity 120,00 g, vitamin A 374.000,00 UI, vitamin B1 40,00 mg, vitamin B12 1.000,00 mcg, vitamin B2 200,00 mg, vitamin B6 54,00 $\mathrm{mg}$, vitamin D3 75.000,00 UI, vitamin E 1.500,00 UI, vitamin $\mathrm{K} 100,00 \mathrm{mg}$ and zinc $4.000,00 \mathrm{mg}$.

heparinized tubes and immediately centrifuged (3500 rpm x $10 \mathrm{~min}$ ) to obtain serum, which was stored at $-20{ }^{\circ} \mathrm{C}$ for further analyses.

The serum levels of total proteins $(\mathrm{g} / \mathrm{dL})$, albumin ( $\mathrm{g} / \mathrm{dL})$, glolubins $(\mathrm{g} / \mathrm{dL})$, triglycerides (mg/dL), cholesterol (mg/dL), uric acid (mg/dL), alanine aminotransferase (ALT) (U/L) and alkaline phosphatase (ALP) (U/L) were evaluated in a semi-automated biochemical analyzer (BioPlus Bio-2000) using commercial kits. Globulins values were calculated by the difference between total serum proteins and albumin. 


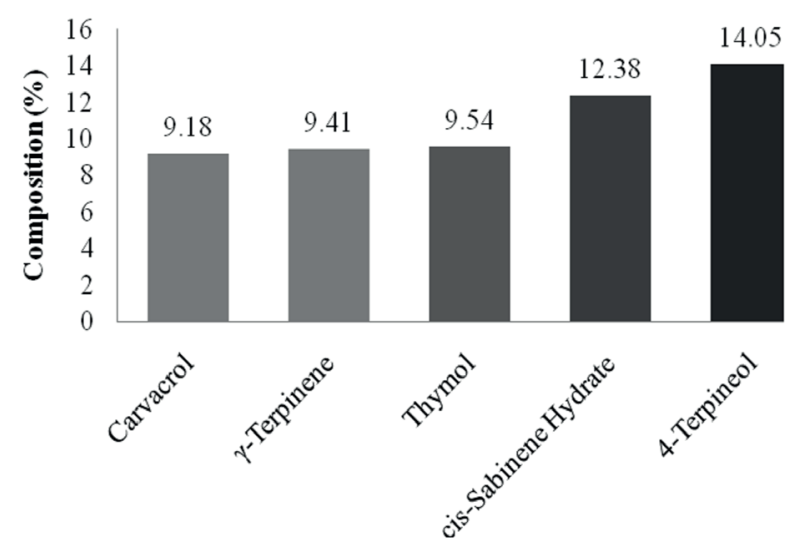

Figure 1 - Composition of Origanum vulgare essential oil (oregano) obtained by gas chromatograph.

\section{STATISTICAL ANALYSIS}

At first, the experimental data were analyzed descriptively, and it was calculated the measure of central tendency (mean) and data of dispersion (standard deviation). Moreover, all variables were submitted to the Shapiro Wilk test to verify if the data were normally distributed. The data was log transformed to meet the assumptions of normality before the application of analyses of variance (ANOVA). The comparison of the means between groups on each observation (days 28, 56 and 84) for all evaluated biochemical variables, followed by Tukey post hoc test $(\mathrm{p}<0.05)$ were carried out with the statistical software R, v.2.15.2 Development Core Team, 2012.

\section{RESULTS}

The percentage of carvacrol, $\gamma$-terpinene, thymol, cis-sabinene hydrate and 4-terpineol, which together add up to approximately $45 \%$ of the volatile compounds $(54.56 \%)$ in the Origanum vulgare essential oil (Figure 1). The values are close to those recommended by Teixeira et al. (2013) and it is important to mention that the composition of the oil depends on many factors such as soil fertility, region and variety of the plant, among others.
The results showed significant differences on total proteins, albumin, globulins and triglyceride levels for the treatments as shown in Tables II and III, in which total protein level had a significant difference for all three sampling days. A significant increase $(p=0.002)$ on total protein was observed on groups T150 and T200 compared to other groups (Table II) on day 28, while on day 56 only the group T50 showed an increase on total proteins compared to groups CT and T0. On day 84, the animals from group T100 showed increased levels of serum total proteins, while the group T200 showed a reduction when compared to CT, T0, T50 and T150 groups.

Regarding the levels of serum albumin (Table II), there were significant differences on days 28 and 84. On day 28 , the hens of group CT showed higher $(p=0.02)$ levels than those of the group T150, while on day 84 the group T0 showed higher $(p=0.04)$ levels than the group T100. The group T200 showed an increase on globulin concentrations compared to groups CT, T0 and T50, as well as groups T100 and 150 showed an increase when compared to groups $\mathrm{CT}$ and $\mathrm{T} 50$.

The serum triglyceride levels (Table III) differ $(\mathrm{p}<0.001)$ for all studied groups only on day 84 , wherein the group T200 showed an increase compared to groups CT, T50, and T100. No differences were observed regarding cholesterol, uric acid, ALT and ALP levels ( $\mathrm{p}>0.05$ ) (Tables III and IV).

\section{DISCUSSION}

The serum biochemical analyses of hens revealed that higher doses of OEO caused changes in the metabolism of proteins by increasing serum levels of globulins, in accordance to results reported by Alp et al. (2012). These authors detected an increase on globulin levels of broilers fed with 300 mg. $\mathrm{kg}^{-1}$ of OEO.

Albumin and globulin represent the most important serum proteins, exerting important physiological functions, such as transportation 
TABLE II

Seric levels of total proteins, albumin and globulin on days 28,56 and 84 post-treatment.

\begin{tabular}{|c|c|c|c|c|c|c|c|c|}
\hline \multicolumn{2}{|l|}{ Variables } & \multicolumn{6}{|c|}{ Mean \pm DP } & \multirow{2}{*}{$\begin{array}{l}\text { p value } \\
0.002^{*}\end{array}$} \\
\hline Total & Day 28 & $\begin{array}{c}\mathrm{CT} \\
7.18^{\mathrm{b}} \\
( \pm 0.77)\end{array}$ & $\begin{array}{c}\text { T0 } \\
7.52^{\mathrm{b}}( \pm 1.43)\end{array}$ & $\begin{array}{c}\text { T50 } \\
6.98^{\mathrm{b}}( \pm 0.61)\end{array}$ & $\begin{array}{c}\mathrm{T} 100 \\
7.78^{\mathrm{b}}( \pm 1.63)\end{array}$ & $\begin{array}{c}\mathrm{T} 150 \\
10.78^{\mathrm{a}} \\
( \pm 3.64)\end{array}$ & $\begin{array}{c}\text { T200 } \\
11.32^{\mathrm{a}}( \pm 2.89)\end{array}$ & \\
\hline (g/dl) & Day 56 & $\begin{array}{c}6.22^{\mathrm{b}} \\
( \pm 0.53)\end{array}$ & $6.38^{\mathrm{b}}( \pm 0.78)$ & $7.68^{\mathrm{a}}( \pm 0.92)$ & $7.17^{\mathrm{ab}}( \pm 0.89)$ & $7.02^{\mathrm{ab}}( \pm 0.25)$ & $7.07^{\mathrm{ab}}( \pm 0.86)$ & $0.020 *$ \\
\hline & Day 84 & $\begin{array}{c}6.33^{b} \\
( \pm 0.63)\end{array}$ & $6.60^{\mathrm{b}}( \pm 0.64)$ & $5.35^{\mathrm{b}}( \pm 0.34)$ & $6.67^{\mathrm{a}}( \pm 1.33)$ & $5.65^{\mathrm{b}}( \pm 0.32)$ & $5.30^{\mathrm{c}}( \pm 0.60)$ & $0.003 *$ \\
\hline \multirow{3}{*}{$\begin{array}{l}\text { Albumin } \\
\text { (g/dl) }\end{array}$} & Day 28 & $\begin{array}{c}2.70^{\mathrm{a}} \\
( \pm 0.43)\end{array}$ & $2.35^{\mathrm{ab}}( \pm 0.87)$ & $1.97^{\mathrm{ab}}( \pm 0.14)$ & $2.02^{\mathrm{ab}}( \pm 0.18)$ & $1.82^{\mathrm{b}}( \pm 0.38)$ & $2.05^{\mathrm{ab}}(0.45)$ & $0.020 *$ \\
\hline & Day 56 & $\begin{array}{c}1.92 \\
( \pm 0.54)\end{array}$ & $1.90( \pm 0.51)$ & $2.13( \pm 0.24)$ & $1.62( \pm 0.59)$ & $2.18( \pm 0.50)$ & $2.15( \pm 0.14)$ & $0.250^{\mathrm{ns}}$ \\
\hline & Day 84 & $\begin{array}{c}1.87^{\mathrm{ab}} \\
( \pm 0.10)\end{array}$ & $2.07^{\mathrm{a}}( \pm 0.12)$ & $1.87^{\mathrm{ab}}( \pm 0.36)$ & $1.65^{\mathrm{b}}( \pm 0.28)$ & $1.73^{\mathrm{ab}}( \pm 0.16)$ & $1.87^{\mathrm{ab}}( \pm 0.12)$ & $0.040 *$ \\
\hline \multirow{3}{*}{$\begin{array}{l}\text { Globulin } \\
\text { (g/dl) }\end{array}$} & Day 28 & $\begin{array}{c}4.32^{c} \\
( \pm 0.51)\end{array}$ & $5.17^{\mathrm{b}}( \pm 1.54)$ & $5.02^{\mathrm{c}}( \pm 0.69)$ & $5.77^{\mathrm{ab}}( \pm 1.70)$ & $8.97^{\mathrm{ab}}( \pm 3.72)$ & $9.27^{\mathrm{a}}( \pm 3.26)$ & $0.001 *$ \\
\hline & Day 56 & $\begin{array}{c}4.30 \\
( \pm 0.99)\end{array}$ & $4.48( \pm 1.14)$ & $5.55( \pm 1.04)$ & $5.55( \pm 1.16)$ & $4.83( \pm 0.54)$ & $4.92( \pm 0.79)$ & $0.150^{\mathrm{ns}}$ \\
\hline & Day 84 & $\begin{array}{c}4.47 \\
( \pm 0.59)\end{array}$ & $4.53( \pm 0.67)$ & $3.48( \pm 0.65)$ & $5.02( \pm 1.37)$ & $3.92( \pm 0.34)$ & $3.43( \pm 0.55)$ & $0.050^{\mathrm{ns}}$ \\
\hline
\end{tabular}

$\overline{{ }^{a}, b, c}$ Different letters in the same line differs statistically between groups by Tukey post hoc test (5\%). Standard deviation (DP), nonsignificative ${ }^{\mathrm{NS}}$ ); Group CT: control treated with $30 \mathrm{mg}$ of zinc bacitracin; Group T0: $0 \%$ of oregano essential oil (OEO); group T50: $50 \mathrm{mg} / \mathrm{kg}^{-1}$ of OEO; group T100: $100 \mathrm{mg} / \mathrm{kg}^{-1}$ of OEO; Group T150: $150 \mathrm{mg} / \mathrm{kg}^{-1}$ of OEO; Group T200: $200 \mathrm{mg} / \mathrm{kg}^{-1}$ of OEO. $* \mathrm{p}<0.05$.

of substances (hormones, vitamins, minerals and lipids), maintenance of plasmatic osmotic pressure and immunity (Polat et al. 2011). The increase on total protein levels, as well as on globulin levels in hens treated with OEO may be attributed to a direct influence on proteic metabolism linked to the immune system (Zhu et al. 2014).

According to Moomivand et al. (2015), the compounds present in essential oils can stimulate the synthesis of proteins and the immune system, protecting the cells against oxidation. These effects were observed by Tollba et al. (2010) using a mixture of 1.0 and $2.0 \mathrm{~g} / \mathrm{kg}$ of oils (thyme, oregano, cinnamon and pepper), with a simultaneous increase on albumin and globulin levels and a reduction of lipid content in chickens. According to these authors, increased levels of globulins is linked to the immunostimulant effects, important to hens immunity (Ghazalah and Ali 2008), i.e., this improvement is linked to a possible response to inflammatory process.

The basal serum levels of total protein in hens varies from 3.0 to $6.0 \mathrm{mg} / \mathrm{dL}$, and values above $6.0 \mathrm{mg} / \mathrm{dL}$, such as observed in this present study, may occur due to dehydration or increased levels of total globulins, hyperglobulinemia associated with diseases or chronic bacterial infections. However, in female hens, the concentration of total proteins increases before the oviposition, which may be attributed to estrogen induction in the ovary, raising globulin levels (Hasegawa et al. 2002). In this study, the increase on serum levels of total proteins 
TABLE III

Seric levels of triglycerides, cholesterols and uric acid (mg/dL) on days 28, 56 and 84 post-treatment.

\begin{tabular}{|c|c|c|c|c|c|c|c|c|}
\hline Variable & & & & Mear & DP & & & $p$ value \\
\hline \multirow{4}{*}{$\begin{array}{c}\text { Triglycerides } \\
\text { (mg/dl) }\end{array}$} & & $\mathrm{CT}$ & T0 & $\mathrm{T} 50$ & $\mathrm{~T} 100$ & $\mathrm{~T} 150$ & $\mathrm{~T} 200$ & \\
\hline & Day 28 & $\begin{array}{c}998.33 \\
( \pm 158.16)\end{array}$ & $\begin{array}{c}1089.83 \\
( \pm 188.94)\end{array}$ & $\begin{array}{c}992 \\
( \pm 118.98)\end{array}$ & $\begin{array}{c}1069.33 \\
( \pm 220.44)\end{array}$ & $\begin{array}{c}1049 \\
( \pm 56.85)\end{array}$ & $\begin{array}{c}995.83 \\
( \pm 237.84)\end{array}$ & $0.870^{\text {ns }}$ \\
\hline & Day 56 & $\begin{array}{c}879.17 \\
( \pm 341.68)\end{array}$ & $\begin{array}{c}878.00 \\
( \pm 210.65)\end{array}$ & $\begin{array}{c}916.83 \\
( \pm 171.15)\end{array}$ & $\begin{array}{c}723.17 \\
( \pm 320.22)\end{array}$ & $\begin{array}{c}874.17 \\
( \pm 153.93)\end{array}$ & $\begin{array}{c}834.17 \\
( \pm 183.20)\end{array}$ & $0.790^{\mathrm{ns}}$ \\
\hline & Day 84 & $\begin{array}{c}986.17^{\mathrm{b}} \\
( \pm 151.42)\end{array}$ & $\begin{array}{l}1097.67^{\mathrm{ab}} \\
( \pm 308.19)\end{array}$ & $\begin{array}{c}708.17^{c} \\
( \pm 134.56)\end{array}$ & $\begin{array}{c}684.67^{\mathrm{c}} \\
( \pm 119.55)\end{array}$ & $\begin{array}{c}987^{\mathrm{ab}} \\
( \pm 101.89)\end{array}$ & $\begin{array}{c}1340.83^{\mathrm{a}} \\
( \pm 236.47)\end{array}$ & $0.001 *$ \\
\hline \multirow{3}{*}{$\begin{array}{l}\text { Cholesterol } \\
\text { (mg/dl) }\end{array}$} & Day 28 & $\begin{array}{c}97.33 \\
( \pm 14.15)\end{array}$ & $\begin{array}{c}103.50 \\
( \pm 34.55)\end{array}$ & $\begin{array}{c}96.83 \\
( \pm 31.75)\end{array}$ & $\begin{array}{c}102.67 \\
( \pm 29.99)\end{array}$ & $\begin{array}{c}96.83 \\
( \pm 24.70)\end{array}$ & $\begin{array}{c}103.33 \\
( \pm 29.62)\end{array}$ & $0.990^{\mathrm{ns}}$ \\
\hline & Day 56 & $\begin{array}{c}89.50 \\
( \pm 21.58)\end{array}$ & $\begin{array}{c}82.17 \\
( \pm 19.36)\end{array}$ & $\begin{array}{c}115.67 \\
( \pm 43.29)\end{array}$ & $\begin{array}{c}102.50 \\
( \pm 40.27)\end{array}$ & $\begin{array}{c}119.17 \\
( \pm 36.41)\end{array}$ & $\begin{array}{c}113.83 \\
( \pm 42.07)\end{array}$ & $0.370^{\mathrm{ns}}$ \\
\hline & Day 84 & $\begin{array}{c}85.33 \\
( \pm 35.56)\end{array}$ & $\begin{array}{c}100.50 \\
( \pm 35.57)\end{array}$ & $\begin{array}{c}115.17 \\
( \pm 36.50)\end{array}$ & $\begin{array}{c}116.67 \\
( \pm 36.52)\end{array}$ & $\begin{array}{c}92.50 \\
( \pm 19.46)\end{array}$ & $\begin{array}{c}80.00 \\
( \pm 20.67)\end{array}$ & $0.440^{\text {ns }}$ \\
\hline \multirow{3}{*}{$\begin{array}{l}\text { Uric acid } \\
\text { (mg/dl) }\end{array}$} & Day 28 & $\begin{array}{c}5.53 \\
( \pm 1.30)\end{array}$ & $5.88( \pm 1.48)$ & $\begin{array}{c}4.93 \\
( \pm 1.01)\end{array}$ & $\begin{array}{c}4.18 \\
( \pm 1.78)\end{array}$ & $\begin{array}{c}6.00 \\
( \pm 1.84)\end{array}$ & $\begin{array}{c}5.38 \\
( \pm 1.11)\end{array}$ & $0.290^{\mathrm{ns}}$ \\
\hline & Day 56 & $\begin{array}{c}5.67 \\
( \pm 1.60)\end{array}$ & $4.22( \pm 1.25)$ & $\begin{array}{c}4.97 \\
( \pm 0.96)\end{array}$ & $\begin{array}{c}5.73 \\
( \pm 1.70)\end{array}$ & $\begin{array}{c}5.70 \\
( \pm 2.15)\end{array}$ & $\begin{array}{c}3.85 \\
( \pm 1.35)\end{array}$ & $0.160^{\text {ns }}$ \\
\hline & Day 84 & $\begin{array}{c}8.93 \\
( \pm 2.99)\end{array}$ & $6.82( \pm 1.95)$ & $\begin{array}{c}6.87 \\
( \pm 2.21)\end{array}$ & $\begin{array}{c}7.20 \\
( \pm 1.40)\end{array}$ & $\begin{array}{c}8.03 \\
( \pm 2.01)\end{array}$ & $\begin{array}{c}7.18 \\
( \pm 1.61)\end{array}$ & $0.470^{\text {ns }}$ \\
\hline
\end{tabular}

$\overline{a, b, c}$ Different letters in the same line differs statistically between groups by Tukey post hoc test (5\%). Standard deviation (DP), nonsignificative $\left({ }^{\mathrm{NS}}\right)$; Group CT: control treated with $30 \mathrm{mg}$ of zinc bacitracin; Group T0: $0 \%$ of oregano essential oil (OEO); group T50: $50 \mathrm{mg} / \mathrm{kg}^{-1}$ of OEO; group T100: $100 \mathrm{mg} / \mathrm{kg}^{-1}$ of OEO; Group T150: $150 \mathrm{mg} / \mathrm{kg}^{-1}$ of OEO; Group T200: $200 \mathrm{mg} / \mathrm{kg}^{-1}$ of OEO. $* \mathrm{p}<0.05$.

may be partially explained by possible hormonal effects associated to the immunostimulatory effect of OEO, increasing globulin levels.

Albumin is a protein responsible for the transport of fatty acids, minerals, uric acid, vitamins and hormones (Maciel et al. 2007). According to Traesel et al. (2011b), the reduction of serum total proteins (albumin and globulin) associated to increased levels of triglycerides suggest hepatic insufficiency (but not hepatic disease), since albumin synthesis occurs only in the liver.

The increase on serum levels of triglycerides on day 84 was observed in hens that received $200 \mathrm{mg}$ of OEO per $\mathrm{kg}$ of feed, similarly to the results observed by Bolukbasi et al. (2006) in broilers supplemented with thyme essential oil. According to these authors, this fact occurs due to an increase on the metabolism of proteins, fat and carbohydrates, associated to an increase on the concentration of triglycerides (Sirvydis et al. 2003). According to Traesel et al. (2011a), the essential oils can produce some toxic effects when administere in higher doses. Thus, it is necessary to establish safety levels in hens in order to avoid health issues.

In a study conducted by Toghyani et al. (2017), it was observed an increase on serum triglyceride levels in hens fed ad libitum. This occurs due to an 
TABLE IV

Seric levels of alanine aminotransferase (ALT) and alkaline phosphatase (ALP) on days 28, 56 and 84 post-treatment.

\begin{tabular}{|c|c|c|c|c|c|c|c|c|}
\hline \multirow[t]{3}{*}{ Variable } & & \multicolumn{6}{|c|}{ Mean \pm DP } & \multirow[t]{2}{*}{ p value } \\
\hline & & CT & T0 & T50 & $\mathrm{T} 100$ & $\mathrm{~T} 150$ & T200 & \\
\hline & Day 28 & $\begin{array}{c}13.73 \\
( \pm 4.96)\end{array}$ & $\begin{array}{c}12.33 \\
( \pm 5.82)\end{array}$ & $\begin{array}{c}14.67 \\
( \pm 6.31)\end{array}$ & $\begin{array}{c}12.33 \\
( \pm 3.61)\end{array}$ & $\begin{array}{c}16.17 \\
( \pm 10.85)\end{array}$ & $\begin{array}{c}13.83 \\
( \pm 7.68)\end{array}$ & $0.190^{\mathrm{ns}}$ \\
\hline \multirow[t]{3}{*}{$\operatorname{ALT}(\mathbf{U} / \mathbf{L})$} & Day 56 & $\begin{array}{c}11.83 \\
( \pm 2.56)\end{array}$ & $\begin{array}{c}10.50 \\
( \pm 0.84)\end{array}$ & $\begin{array}{c}9.33 \\
( \pm 3.20)\end{array}$ & $\begin{array}{c}10.17 \\
( \pm 4.12)\end{array}$ & $\begin{array}{c}8.50 \\
( \pm 3.56)\end{array}$ & $\begin{array}{c}8.00 \\
( \pm 3.63)\end{array}$ & $0.340^{\mathrm{ns}}$ \\
\hline & Day 84 & $\begin{array}{c}8.50 \\
( \pm 3.62)\end{array}$ & $\begin{array}{c}8.50 \\
( \pm 2.66)\end{array}$ & $\begin{array}{c}8.33 \\
( \pm 5.32)\end{array}$ & $\begin{array}{c}8.50 \\
( \pm 3.33)\end{array}$ & $\begin{array}{c}8.17 \\
( \pm 2.56)\end{array}$ & $\begin{array}{c}7.83 \\
( \pm 2.71)\end{array}$ & $0.990^{\mathrm{ns}}$ \\
\hline & Day 28 & $\begin{array}{c}178.50 \\
( \pm 70.94)\end{array}$ & $\begin{array}{c}255.00 \\
( \pm 79.63)\end{array}$ & $\begin{array}{c}248.50 \\
( \pm 98.32)\end{array}$ & $\begin{array}{c}215.00 \\
( \pm 115.49)\end{array}$ & $\begin{array}{c}247.50 \\
( \pm 115.89)\end{array}$ & $\begin{array}{c}213.83 \\
( \pm 34.45)\end{array}$ & $0.670^{\mathrm{ns}}$ \\
\hline \multirow[t]{2}{*}{$\operatorname{ALP}(\mathbf{U} / \mathbf{L})$} & Day 56 & $\begin{array}{c}193.17 \\
( \pm 72.73)\end{array}$ & $\begin{array}{c}142.00 \\
( \pm 25.50)\end{array}$ & $\begin{array}{c}124.00 \\
( \pm 53.58)\end{array}$ & $\begin{array}{c}179.50 \\
( \pm 78.31)\end{array}$ & $\begin{array}{c}187.33 \\
( \pm 68.51)\end{array}$ & $\begin{array}{c}170.00 \\
( \pm 56.75)\end{array}$ & $0.330^{\mathrm{ns}}$ \\
\hline & Day 84 & $\begin{array}{c}180.50 \\
( \pm 47.09)\end{array}$ & $\begin{array}{c}142.00 \\
( \pm 44.69)\end{array}$ & $\begin{array}{c}165.33 \\
( \pm 71.60)\end{array}$ & $\begin{array}{c}175.17 \\
( \pm 56.87)\end{array}$ & $\begin{array}{c}199.83 \\
( \pm 78.01)\end{array}$ & $\begin{array}{c}203.67 \\
( \pm 78.90)\end{array}$ & $0.590^{\mathrm{ns}}$ \\
\hline
\end{tabular}

Standard deviation (DP), non-significative $\left({ }^{\mathrm{NS}}\right)$; Group CT: control treated with $30 \mathrm{mg}$ of zinc bacitracin; Group T0: $0 \%$ of oregano essential oil (OEO); group T50: $50 \mathrm{mg} / \mathrm{kg}^{-1}$ of OEO; group T100: $100 \mathrm{mg} / \mathrm{kg}^{-1}$ of OEO; Group T150: $150 \mathrm{mg} / \mathrm{kg}^{-1}$ of OEO; Group T200: $200 \mathrm{mg} / \mathrm{kg}^{-1}$ of OEO. $\mathrm{p}<0.05$.

increase on very low-density lipoprotein (VLDL) in serum, the main triglyceride transporter. It may be considered an indicator of changes in hepatic secretion of VLDL and hepatic lipogeneses (synthesis of triglycerides and fatty acids). Other explanation might be linked to the catabolism of fatty acids and regulation of energetic metabolism, which affect directly physiological responses.

According to Melo et al. (2016), the addition of new elements to feed may cause an increase on the mobilization of triglycerides from tissues to blood flow. Concentrations of triglycerides and cholesterol in hens that received feed supplementation of natural additives may be linked to antioxidant and antibacterial properties (Gálik et al. 2015). Some factors contribute to these results, such as age, sex, type of hens, nutritional and physiological status, 189 as well as differences on oil composition (Moomivand et al. 2015, Akbari and Mehran 2014). However, this increase on the levels of triglycerides in hens is not considered a negative effect on their health.

Bampidis et al. (2005) observed the absence of differences regarding the plasmatic cholesterol levels in turkeys fed with dried oregano leaves, similarly to the results observed in this study. Moreover, diets used for broilers containing carvacrol and thymol (Lee et al. 2003b) and used for laying hens with a mixture of essential oils (Bozkurt et al. 2012) caused no differences on cholesterols levels. This non-significant effect may be associated to OEO components that were ineffective in the inhibition of the enzyme 3-hidroxi-3-methyl-glutaril198 CoA reductase (HMG-CoA reductase), which is a limitant on cholesterol synthesis (Khattak et al. 2014).

A study conducted by Basmacioglu Malayoğlu et al. (2010) reported that thymol and carvacrol may exhibit hypocholesterolemic effects by the inhibition of HMG-CoA reductase. Moreover, 
a reduction on lipid content and total cholesterol levels in a diet containing rosemary oil for broilers can be attributed to thymol and carvacrol compounds (Polat et al. 2011). However, despite the presence of thymol and carvacrol on OEO used in this study, decreased levels of serum triglycerides was not observed, probably due to the amount of OEO used in this study.

No differences regarding serum uric acid levels, as well as on ALT and alkaline phosphatase levels were observed for the studied groups. Since uric acid is synthetized in the liver and kidneys, renal changes can increase the serum or plasmatic concentration of uric acid in laying hens (Schmidt et al. 2007), being involved in antioxidants functions, and is the major product of purine catabolism. According to Zhu et al. (2014), hepatic damages or increased permeability of hepatic cells increased the serum ALT levels. This increase was not observed in the present study. The alkaline phosphatase (ALP) activity produced by many organs, such as liver, is an important marker of bone metabolism, and the age of poultry may increase or decrease its activity (Zhu et al. 2014). The increase on serum biomarkers of hepatic function is correlated to hepatic oxidative lesions, and serum ALT and ALP activities are considerable sensible indicators of hepatic cellular lesion (Botsoglou et al. 2008). The intestinal ALP showed important functions, such as regulating the absorption of lipids by the intestine, and a significant reduction on ALP activity in chickens fed with a diet containing oregano was linked with improved lipid digestibility (Levkut et al. 2011). The activity of ALP did not differ for the investigated treatments, therefore, OEO treatment did not cause hepatic injury. One of the main problem linked with the use of essential oils in the diet is the component variation, leading to no effect in some moments (Basmacioglu Malayoğlu et al. 2010).

Based on these results, it is noted that the use of $200 \mathrm{mg}$ of $\mathrm{OEO} / \mathrm{kg}$ has an immunostimulatory effect on the first phase of the production cycle, but it caused no increased on globulins levels. Later, the use of OEO increased serum levels of triglycerides. In summary, it is concluded that the treatment with OEO exerts beneficial effects on bird health without any side effect. In addition, there is a need of more studies to evaluate wheather OEO may enhance egg quantity and quality.

\section{ACKNOWLEDGMENTS}

We would like to tkank to Fundo de Apoio à Manutenção e ao Desenvolvimento da Educação Superior/FUMDES (Scholarship).

\section{REFERENCES}

ABDEL-WARETH AAA. 2016. Effect of dietary supplementation of thymol, symbiotic and their combination on performance, egg quality and serum metabolic profile of Hy-Line Brown hens. Brit Poultry Sci 57(1): 114-122.

AKBARI M AND MEHRAN T. 2014. Effects of dietary chromium picolinate and peppermint essential oil on growth performance and blood biochemical parameters of broiler chicks reared under heat stress conditions. Int J Biometeorol 58(6): 1383-1391.

ALP M, MIDILLI M, KOCABAGLI N, YILMAZ H, TURAN N, GARGILI A AND ACAR N. 2012. The effects of dietary oregano essential oil on live performance, carcass yield, serum immunoglobulin $\mathrm{G}$ level, and oocyst count in broilers. J Appl Poult Res 21(3): 630-636.

BAMPIDIS VA, CHRISTODOULOU V, FLOROU-PANERI P, CHRISTAKI E, CHATZOPOULOU PS, TSILIGIANNI T AND SPAIS AB. 2005. Effect of dietary dried oregano leaves on growth performance, carcass characteristics and serum cholesterol of female early maturing turkeys. $\mathrm{Br}$ Poult Sci 46(5): 595-601.

BASMACIOGLU MALAYOGLU H, BAYSAL S, MISIRLIOGLU Z, POLAT M, YILMAZ H AND TURAN N. 2010. Effects of oregano essential oil with or without feed enzymes on growth performance, digestive enzyme, nutrient digestibility, lipid metabolism and immune response of broilers fed on wheat-soybean meal diets. $\mathrm{Br}$ Poult Sci 51(1): 67-80.

BOLUKBASI SC, ERHAN MK AND OZKAN A. 2006. Effect of dietary thyme oil and vitamin $\mathrm{E}$ on growth, lipid oxidation, meat fatty acid composition and serum lipoproteins of broilers. S Afri J Anim Sci 36(3): 189-196. 
BOTSOGLOU NA, FLOROU-PANERI P, CHRISTAKI E, FLETOURIS DJ AND SPAIS AB. 2002. Effect of dietary oregano essential oil on performance of chickens and on iron-induced lipid oxidation of breast, thigh and abdominal fat tissues. Br Poult Sci 43(2): 223-230.

BOTSOGLOU NA, TAITZOGLOU IA, BOTSOGLOU E, LAVRENTIADOU SN, KOKOLI AN AND ROUBIES N. 2008. Effect of long-term dietary administration of Oregano on the alleviation of carbon tetrachloride-induced oxidative stress in rats. J Agric Food Chem 56(15): 62876293.

BOZKURT M, TOKUSOGLU O, KUÇUKYILMAZ K, AKSIT H, CABUK M, UGUR ÇATLI A, SEYREK K AND ÇINAR M. 2012. Effects of dietary mannan oligosaccharide and herbal essential oil blend supplementation on performance and oxidative stability of eggs and liver in laying hens. Ital J Anim Sci 11(2): e41.

CASE GL, HE L, MO H AND ELSON CE. 1995. Induction of geranyl pyrophosphate pyrophosphatase activity by cholesterol-suppressive isoprenoids. Lipids 30(4): 357359.

GÁLIK B, WILKANOWSKA A, BIRO D, ROLINEC M, SIMKO M, JURÁCEK M AND MAIORANO G. 2015. Effect of a phytogenic additive on blood serum indicator levels and fatty acids profile in fattening turkeys meat. $\mathrm{J}$ Cent Eur Agr 16(4): 383-398.

GERZILOV V, NIKOLOV A, PETROV P, BOZAKOVA N, PENCHEV G AND BOCHUKOV A. 2015. Effect of a dietary herbal mixture supplement on the growth performance, egg production and health status in chickens. J Cent Eur Agr 16(2): 10-27.

GHAZALAH AA AND ALI AM. 2008. Rosemary leaves as a dietary supplement for growth in broiler chickens. Int $\mathrm{J}$ Poult Sci 7(3): 234-239.

HASEGAWA MY, FONTEQUE JH, KOHAYAGAWA A AND BORETTI LP. 2002. Avaliação do perfil eletroforético das proteínas séricas em matrizes pesadas (Gallus Gallus domesticus) da Linhagem Avian Farm. Rev Bras Cienc Avic, p. 203-207.

HASHEMIPOUR H, KERMANSHAHI H, GOLIAN A, RAJI AR AND VAN KRIMPEN MM. 2013. Effect of thymol+ carvacrol by next enhance $150 \AA$ on intestinal development of broiler chickens fed CMC containing diet. Iran J Appl Anim Sci 3(3): 567-576.

KHATTAK F, RONCHI A, CASTELLI P AND SPARKS N. 2014. Effects of natural blend of essential oil on growth performance, blood biochemistry, cecal morphology, and carcass quality of broiler chickens. Poult Sci 93(1): 132137.

LEE KW, EVERTS H, KAPPERT HJ, FREHNER M, LOSA R AND BEYNEN AC. 2003a. Effects of dietary essential oil components on growth performance, digestive enzymes and lipid metabolism in female broiler chickens. Br Poult Sci 44(3): 450-457.

LEE KW, EVERTS H, KAPPERT HJ, YEOM KH AND BEYNEN AC. 2003b. Dietary carvacrol lowers body weight gain but improves feed conversion in female broiler chickens. J Appl Poult Res 12(4): 394-399.

LEVKUT M, MARCIN A, REVAJOVÁ V, LENHARD L, DANIELOVIC I, HECL J AND PISTL J. 2011. Influence of oregano extract on the intestine, some plasma parameters and growth performance in chickens. Acta Vet Brno 61(23): 215-225.

MACIEL RM, LOPES STDA, SANTURIO JM, ROSA AP, DUARTE MMMF, MARTINS DB AND EMANUELLI MP. 2007. Electrophoresis profile of serum proteins in broilers fed with diets containing aflatoxins and/or natural clinoptilolite clay. Cienc Rural 37(3): 744-749.

MELO RD, CRUZ FGG, FEIJÓ JDC, RUFINO JPF, MELO LD AND DAMASCENO L. 2016. Black pepper (Piper nigrum) in diets for laying hens on performance, egg quality and blood biochemical parameters. Acta Sci Anim Sci 38(4): 405-410.

MOOMIVAND H, SEIF Y, TALEGHANI M, OSHTOLAG AM AND DARZAN M. 2015. The effect of drinking thyme essence on proteins, enzymatic activity, serum biochemical parameters and hematological characteristics in broiler chicks. Int J Biosci 6(3): 264-273.

POLAT U, YESILBAG D AND EREN M. 2011. Serum biochemical profile of broiler chickens fed diets containing rosemary and rosemary volatile oil. J Biol Environ Sci 5(13): 23-30.

R CORE TEAM. 2012. R: A language and environment for statistical computing. R Foundation for Statistical Computing, Vienna, Austria.

ROOFCHAEE A, IRANI M, ALI EBRAHIMZADEH M AND REZA AKBARI M. 2011. Effect of dietary oregano (Origanum vulgare L.) essential oil on growth performance, cecal microflora and serum antioxidant activity of broiler chickens. Afr J Biotechnol 10(32): 6177-6183.

ROSA NETO NS AND CARVALHO JFD. 2009. O uso de provas de atividade inflamatória em reumatologia. Rev Bras Reumatol 49(4): 413-430.

ROSTAGNO HS, ALBINO LFT, DONZELE JL, GOMES PC, OLIVEIRA RD, LOPES DC, FERREIRA AS AND BARRETO SLT. 2011. Tabelas brasileiras para aves e suínos: composição de alimentos e exigências nutricionais. Minas Gerais, Brasil: Universidade Federal de Viçosa, 186 p.

SCHMIDT EMS, LOCATELLI-DITTRICH R, SANTIN E AND PAULILLO AC. 2007. Patologia clínica em aves de produção-uma ferramenta para monitorar a sanidade avícola - revisão. Arch Vet Sci 12(3): 9-20.

SIRVYDIS VH, BOBINIENE R, PRIUDOKIENE V AND VENCIUS D. 2003 Phytobiotics add value to broiler feed. World Poult 19(1): 16-17. 
TEIXEIRA B, MARQUES A, RAMOS C, SERRANO C, MATOS O, NENG NR, NOGUEIRA JMF, SARAIVA JA AND NUNES ML. 2013. Chemical composition and bioactivity of different oregano (Origanum vulgare) extracts and essential oil. J Sci Food Agric 93(11): 27072714.

TOGHYANI M, GIRISH CK, WU SB, IJI PA AND SWICK RA. 2017. Effect of elevated dietary amino acid levels in high canola meal diets on productive traits and cecal microbiota population of broiler chickens in a pair-feeding study. Poult Sci 96(5): 1268-1279.

TOLLBA AAH, SHABAAN SAM AND ABDEL-MAGEED MAA. 2010. Effects of using aromatic herbal extract and blended with organic acids on productive and physiological performance of poultry 2-the growth during cold winter stress. Egypt Poul Sci 30: 229-248.

TRAESEL CK, LOPES STDA, WOLKMER P, SCHMIDT C, SANTURIO JM AND ALVES SH. 2011a. Óleos essenciais como substituintes de antibióticos promotores de crescimento em frangos decorte: perfil de soroproteínas e peroxidação lipídica. Cienc Rural 41(2): 278-284.

TRAESEL CK, WOLKMER P, SCHMIDT C, SILVA CB, PAIM FC, ROSA AP AND LOPES ST. 2011b. Serum biochemical profile and performance of broiler chickens fed diets containing essential oils and pepper. Comp Clin Path 20(5): 453-460.

ZHANG KY, YAN F, KEEN CA AND WALDROUP PW. 2005. Evaluation of microencapsulated essential oils and organic acids in diets for broiler chickens. Int J Poult Sci 4(9): 612-619.

ZHU X, LIU W, YUAN S AND CHEN H. 2014.The effect of different dietary levels of thyme essential oil on serum biochemical indices in Mahua broiler chickens. Ital J Anim Sci 13(3): 576-581. 